\title{
PENGARUH KONSELING FARMASIS DALAM MENINGKATKAN KEPATUHAN PASIEN DIABETES MELITUS MENGGUNAKAN OBAT ANTIDIABETES DI PERUM KETAPANG SOKARAJA KULON
}

\author{
Ikhwan Yuda Kusuma ${ }^{1)}$, Rani Prabandani ${ }^{2)}$ \\ ${ }^{11,2)}$ Program Studi Farmasi Sekolah Tinggi Ilmu Kesehatan Harapan Bangsa Purwokerto \\ 1) $\underline{\text { kkhwanyuda@ shb.ac.id, }},{ }^{2)}$ Raniprabandari@shb.ac.id
}

\begin{abstract}
ABSTRAK
Hasil survei WHO menunjukkan bahwa jumlah penderita DM di Indonesia menduduki ranking ke-4 terbesar di dunia. Penyakit DM menyebabkan kematian sebesar 5\% setiap tahunnya. Kematian akibat DM diperkirakan akan meningkat sebesar 50\% pada sepuluh tahun yang akan datang. Hasil RISKESDAS Jawa Tengah 2007 menunjukkan bahwa prevalensi penyakit DM di provinsi Jawa Tengah yaitu sebesar 0,8\% dan secara keseluruhan sebesar 1,3\%. Prevalensi tertinggi terdapat di Kabupaten Cilacap (3,9\%), urutan kedua yaitu Kabupaten Tegal Kota $(3,1 \%)$, untuk urutan ketiga yaitu Surakarta $(2,8 \%)$, urutan keempat yaitu Pemalang $(2,1 \%)$, dan urutan kelima diduduki Banyumas (1,9\%) (Depkes,2009). Penelitian ini menggunakan rancangan eksperimental dengan melakukan perlakuan terhadap kelompok kasus.Instrumen penelitian dalam penelitian ini adalah panduan wawancara tentang jumlah sisa obat antidiabetes untuk mengecek kepatuhan dan kuesioner MMAS yang sudah di validasi dan translasi versi Indonesia (Setyaningsih, 2013). Hasil analisa data dengan uji Chi-Square diperoleh $\mathrm{p}=0,220(\mathrm{p}>0,05)$ berdasarkan kuesioner MMAS, hal ini menunjukkan bahwa pemberian informasi obat tidak ada pengaruh terhadap tingkat kepatuhan penggunaan antidiabetes pada pasien DM di Perum Ketapang Sokaraja Kulon.
\end{abstract}

Kata Kunci : Gula darah, Diabetes Melitus, Informasi Obat,

\section{ABSTRACT}

The WHO survey results show that the number of DM patients in Indonesia is ranked the 4th largest in the world. DM causes death by 5\% every year. Deaths from DM are expected to increase by $50 \%$ in the next ten years. The results of the 2007 Central Java RISKESDAS showed that the prevalence of DM in Central Java province was $0.8 \%$ and overall was $1.3 \%$. The highest prevalence is found in Cilacap Regency (3.9\%), second place is Tegal City Regency (3.1\%), for the third place is Surakarta (2.8\%), fourth place is Pemalang (2.1\%), and fifth place is occupied by Banyumas (1.9\%) (Ministry of Health, 2009). This study used an experimental design by treating the group of cases. The research instruments in this study were interview guides about the number of remaining antidiabetic drugs to check the compliance and MMAS questionnaires that had been validated and translated into Indonesian versions (Setyaningsih, 2013). The results of the data analysis using the Chi-Square test were obtained $p=0.220(p>0.05)$ based on the MMAS questionnaire, this indicates that the administration of drug information had no effect on the level of adherence to antidiabetic use in DM patients at Ketapang Sokaraja Kulon.

Keywords: Blood Sugar, Diabetes Mellitus, Drug Information 


\section{PENDAHULUAN}

Hasil survei WHO menunjukkan bahwa jumlah penderita DM di Indonesia menduduki ranking ke-4 terbesar di dunia. Penyakit DM menyebabkan kematian sebesar 5\% setiap tahunnya. Kematian akibat DM diperkirakan akan meningkat sebesar $50 \%$ pada sepuluh tahun yang akan datang. Hasil RISKESDAS Jawa Tengah 2007 menunjukkan bahwa prevalensi penyakit DM di provinsi Jawa Tengah yaitu sebesar $0,8 \%$ dan secara keseluruhan sebesar $1,3 \%$. Prevalensi tertinggi terdapat di Kabupaten Cilacap (3,9\%), urutan kedua yaitu Kabupaten Tegal Kota (3,1\%), untuk urutan ketiga yaitu Surakarta (2,8\%), urutan keempat yaitu Pemalang (2,1\%), dan urutan kelima diduduki Banyumas (1,9\%) (Depkes, 2009).

Pelayanan kefarmasian merupakan bagian integral dari sistem pelayanan kesehatan yang tidak terpisahkan. Salah satu aspek pelayanan kefarmasian adalah pelayanan residensial kefarmasian yang penyelenggaraannya telah diatur dalam Pedoman Home Pharmacy Care tahun 2008. Pelaksanaan jaminan kesehatan yang diatur dalam pasal 22 Peraturan
Presiden Nomor 12 Tahun 2013 mengenai jaminan kesehatan yaitu pelayanan kesehatan tingkat pertama dan pelayanan kesehatan lanjutan, dimana pelayanan kesehatan tingkat pertama memberikan pelayanan yang bersifat preventif dan promotif kepada peserta serta dalam pelayanannya terdapat kerja kerjasama antara dokter, perawat dan farmasis. Hasil penelitian menunjukkan bahwa pelayanan residensial kefarmasian mampu meningkatkan kepatuhan penggunaan obat pasien dan diet pada pasien, sehingga dapat menunjang keberhasilan terapi pasien (Ichwari et al., 2013).

Komplikasi DM dapat dicegah dengan meningkatkan kepatuhan penggunaan obat dan diet pasien sehingga dapat memaksimalkan outcome terapi (Depkes, 2005). Kepatuhan terhadap pengobatan adalah faktor utama dari outcome terapi (Morello et al., 2011). Penelitian Cramer (2004) menunjukkan bahwa beberapa pasien DM tipe 2 tidak mengkonsumsi sepenuhnya obat diabetes oral yang diresepkan oleh dokter dan tingkat kepatuhan secara keseluruhan menurun setiap waktu. Faktor-faktor yang dapat mempengaruhi kepatuhan meliputi 
pemahaman pasien dari regimen dan manfaatnya, efek samping yang potensial, biaya dan kompleksitas dari terapi (Osterberg and Blaschke, 2005). Kompleksitas regimen obat dipengaruhi oleh jumlah obat, frekuensi pemberian, bentuk sediaan dan juga instruksi pemberian khusus (Pollack et al., 2010).

Berdasarkan adanya penerapan program jaminan kesehatan dan hasil survei yang menunjukkan bahwa Surakarta menjadi peringkat ketiga dalam jumlah penderita diabetes serta tingkat kepatuhan pasien DM yang masih rendah, maka peneliti bermaksud untuk melakukan konseling dengan menggunakan alat bantu (lembar informasi penggunaan obat dan telepon) serta melihat hubungannya terhadap tingkat kepatuhan, outcome klinik dan tingkat kepuasan pasien DM tipe2 . Penelitian ini diharapkan bahwa dengan adanya peningkatan kepatuhan maka outcome klinik akan tercapai dan tingkat kepuasan pasien juga menjadi semakin meningkat.

\section{METODE PENELITIAN}

Penelitian ini menggunakan rancangan eksperimental dengan melakukan perlakuan terhadap kelompok kasus. Subjek dialokasikan secara random atau penelitian acak terkontrol dengan cara pengambilan data secara prospektif atau data diambil setelah penelitian dimulai dan lebih melihat ke depan (Perwitasari, 2010). Tujuan penelitian ini adalah untuk mengetahui pengaruh suatu variabel independen (pemberian informasi obat) terhadap variabel dependen (kepatuhan pasien). Penelitian dilakukan dengan mengamati pasien DM yang diberi informasi obat (kelompok kasus) dan tanpa informasi obat (kelompok kontrol) saat pengambilan obat, kemudian mengamati tingkat kepatuhan pasien dalam minum obat antidiabetes.

Instrumen penelitian dalam penelitian ini adalah panduan wawancara tentang jumlah sisa obat antidiabetes untuk mengecek kepatuhan dan kuesioner MMAS yang sudah di validasi dan translasi versi Indonesia (Setyaningsih, 2013). Data rekam medik untuk mengetahui data pasien dan hasil diagnosa pasien DM oleh dokter.

Sampel yang digunakan dalam penelitian ini yaitu menggunakan pasien yang terdiagnosa DM dengan melihat kartu kendali atau kartu kontrol kesehatan pasien yang sudah tertulis atau terdata oleh petugas kesehatan dan mendapatkan antidiabetes oleh dokter di Perum Ketapang Sokaraja Kulon pada tanggal 30 Mei 201830 Mei 2018 08.00-12.00 WIB. Jumlah 
sampel pada penelitian ini diperoleh variable).

sebanyak 44 responden.

Peneliti dalam mengumpulkan data pasien DM pada Bulan Mei 2018. Data yang diambil meliputi nama obat, umur, dan alamat pasien. Data mengenai kepatuhan pasien DM menggunakan data primer, yaitu melalui wawancara secara langsung kepada pasien, yaitu data dari jumlah sisa obat yang diminum oleh pasien pada hari ke 3 serta pengisian kuesioner MMAS.

Data dianalisis statistik ChiSquare bertujuan untuk mengetahui adanya hubungan atau pengaruh dua variable nominal (Uji independen antara dua

\section{HASIL DAN PEMBAHASAN}

\subsection{Hasil tingkat kepatuhan pasien}

\section{berdasarkan kuesioner MMAS}

a. Tingkat kepatuhan pasien yang diberi informasi dan tanpa informasi Pada penelitian ini untuk mengetahui tingkat kepatuhan pasien DM yang diberi informasi obat dan tanpa informasi obat. Berdasarkan hasil kuesioner MMAS kepatuhan tinggi jika skor yang dimiliki pasien adalah 8, kepatuahan rendah jika skor yang dimiliki pasien adalah $<8$, dan diperoleh data seperti pada Tabel I.

Tabel 1. Tingkat kepatuhan pasien DM

\begin{tabular}{|c|c|c|c|}
\hline Kepatuhan & Diberi informasi & Tanpa informasi & Total \\
\hline Rendah & 7 & 11 & 18 \\
\hline Tinggi & 15 & 11 & 26 \\
\hline Total & 22 & 22 & 44 \\
\hline \multicolumn{2}{|c|}{ Berdasarkan hasil kuesioner } & \multicolumn{2}{|c|}{$\begin{array}{l}\text { responden dan tingkat kepatuhan } \\
\text { rendah dengan jumlah } 7 \text { responden, }\end{array}$} \\
\hline \multicolumn{2}{|c|}{ MMAS pada pasien DM yang diberi } & & \\
\hline $\begin{array}{l}\text { informasi } \\
\text { kepatuhan tin }\end{array}$ & $\begin{array}{l}\text { miliki } \quad \text { tingkat } \\
\text { lengan jumlah } 15\end{array}$ & \multicolumn{2}{|c|}{$\begin{array}{l}\text { hal ini menunjukan pentingnya } \\
\text { pemberian informasi obat sehingga }\end{array}$} \\
\hline
\end{tabular}


memberikan tingkat kepatuhan yang tinggi pada pasien dalam penggunaan obat antidiabetes dibandingkan tanpa pemberian informasi obat. Berdasarkan penelitian (Putriani, 2013) menggunakan kuesioner MMAS pada pasien hipertensi hasil yang diperoleh jumlah pasien dengan tingkat kepatuhan tinggi lebih banyak dengan pemberian informasi obat yaitu 22 responden dan tingkat kepatuhan rendah 7 responden.

b. Pengaruh Pemberian Informasi Obat Terhadap Tingkat Kepatuhan

Pada penelitian ini peneliti ingin mengetahui pengaruh pemberian informasi obat terhadap tingkat kepatuhan. Dari hasil wawancara berdasarkan

kuisioner MMAS diperoleh data dari hasil uji statistik seperti pada Tabel III.

\begin{tabular}{ccccccc}
\hline Kelompok & \multicolumn{2}{c}{ Tingkat Kepatuhan } & Total & $\mathrm{p}$ & $\mathrm{OR}$ & $\mathrm{Cl}$ \\
\cline { 2 - 4 } & Rendah & Tinggi & & & & \\
\hline Diberi & 7 & 15 & 22 & 0,220 & 0,467 & $0,137-$ \\
Informasi & & & & & & 1,590 \\
\hline $\begin{array}{c}\text { Tanpa } \\
\text { Informasi }\end{array}$ & 11 & 11 & 22 & & & \\
\hline Total & 18 & 26 & 44 & & & \\
\hline
\end{tabular}

Berdasarkan hasil uji statistik patuh dalam minum obat antidiabetes. dengan uji Chi-Square diperoleh data hasil Namun, ada juga pasien yang memiliki pengaruh pemberian informasi obat kesadaran sendiri untuk minum obat terhadap tingkat kepatuhan dengan nilai antidiabetes karena memiliki keinginan $\mathrm{p}=0,220 \quad(\mathrm{p}>0,05)$. Hal ini menunjukkan untuk sembuh atau lebih memperhatikan bahwa informasi obat tidak terdapat kesehatannya.

hubungan yang signifikan terhadap tingkat kepatuhan pasien DM pada penggunaan antidiabetes. Karena peneliti kurang lengkap dalam memberikan informasi 4.2.Hasil kepatuhan pasien berdasarkan jumlah sisa obat kepada pasien serta kurangnya pengetahuan kepatuhan pasien berdasarkan kuesioner pasien dalam penggunaan antidiabetes. MMAS peneliti membuktikan kebenaran Sehingga, masih ada pasien yang tidak kepatuhan pasien DM dalam penggunaan 
antidiabetes berdasarkan jumlah sisa obat yang dilihat saat peneliti berkunjung kerumah pasien pada hari ke-3.

a. Kepatuhan pasien DM berdasar-kan jumlah sisa obat

Pada penelitian ini untuk mengetahui kepatuhan pasien DM yang diberi informasi obat dan tanpa informasi obat, berdasarkan jumlah sisa obat diperoleh data seperti pada Tabel IV.

Berdasarkan data sisa obat yang diperoleh dari hasil wawancara pada hari ke-3 dirumah pasien, pada pasien DM yang diberi informasi obat memiliki kepatuhan dengan jumlah 21 responden dan yang tidak patuh dengan jumlah 1 responden. Hal ini menunjukkan informasi obat yang diberikan pada pasien dapat menjadi salah satu tercapainya keberhasilan terapi sehingga banyaknya pasien yang patuh dalam penggunaan antidiabetes. Sedangkan pada pasien yang tanpa diberikan informasi obat tapi tetap patuh dalam penggunaan antidiabetes kemungkinan adanya kesadaran masing-masing pasien dalam penggunaan antidiabetes untuk sembuh atau sudah adanya pengetahuan tentang penggunaan antidiabetes.

Tabel IV. Kepatuhan pasien DM berdasarkan sisa jumlah obat

\begin{tabular}{cccc}
\hline Kelompok & \multicolumn{2}{c}{ Kepatuhan Berdasarkan Sisa Obat } & Persentase \\
\hline Diberi Informasi & Patuh & 21 & $47,73 \%$ \\
\cline { 2 - 4 } & Tidak Patuh & 1 & $2.27 \%$ \\
\hline Tanpa Informasi & Patuh & 17 & $38,64 \%$ \\
\cline { 2 - 4 } & Tidak patuh & 5 & $11,36 \%$ \\
\hline Total & 44 & & $100 \%$ \\
\hline \multirow{2}{*}{ KESIMPULAN } & & pemberian informasi obat tidak ada
\end{tabular}

Berdasarkan hasil penelitian dapat disimpulkan bahwa analisa data dengan penggunaan antidiabetes pada pasien uji Chi-Square diperoleh $\mathrm{p}=0,220$ DM di Perum Ketapang Sokaraja $(p>0,05) \quad$ berdasarkan kuesioner Kulon.

MMAS, hal ini menunjukkan 


\section{DAFTAR PUSTAKA}

Ahmad, N.S., Ramli, A., Islahudin, F., Paraidathathu, T., 2013. Medication Adherence in Patients with Tipe 2 Diabetes Mellitus Treated at Primary Health Clinics in Malaysia. Patient Prefer Adherence. Dove Medical Press 7 , 525-530. doi:10.2147/PPA.S44698

American Diabetes Association, 2012. Standards of Medical Care in Diabetes-- 2012. Diabetes Care, 35, S11-S63. doi:10.2337/dc12S011

American Diabetes Association, 2014. Standards of Medical Care in Diabetes-- 2014. Diabetes Care, 37, S14-S80. doi: 10.2337/dc14S014

American Diabetes Association., 2015. American Diabetes Association Standards of Medical Care in Diabetes-2015. Diabetes Care, 38, S1-S94.

Anderson, R.T., Girman, C.J., Pawaskar, M.D., Camacho, F.T., Calles, J., Kelly, W.S., DeMuro, C., Balkrishnan, R., 2009. Diabetes Medication Satisfaction Tool A focus on treatment regimens. Diabetes Care 32, 51- 53. doi:10.2337/dc08-0856

Anonim. 2013. Peraturan Presiden Republik Indonesia Nomor 12 tahun 2013 tentang Jaminan
Kesehatan.

Avramopoulos, I., Moulis, A., Nikas, N., 2015. Glycaemic control, treatment satisfaction and quality of life in type 2 diabetes patients in Greece: The PANORAMA study Greek results. World J. Diabetes 6, 208-216. doi:10.4239/wjd.v6.i1.208

Barbosa, CD., Balp MM, Kulich, K., Germain N., Rofail D., 2012., A Literature Review to Explore The Link Between treatment Satisfaction and Adherence, Compliance, and Persistence. Patient Prefer Adherence; 6: 3949.

BPJS Kesehatan, 2013. Panduan Praktis PROLANIS (Program Pengelolaan Penyakit kronis). BPJS Kesehatan. Jakarta.

Avramopoulos, I., Moulis, A., Nikas, N., 2015. Glycaemic control, treatment satisfaction and quality of life in type 2 diabetes patients in Greece: The PANORAMA study Greek results. World J. Diabetes 6, 208-216. doi:10.4239/wjd.v6.i1.208

Bradley, C., Lewis, K.S., 1990. Measures of psychological well-being and treatment satisfaction developed from the responses of people with tablet- treated diabetes. Diabet. Med. J. Br. Diabet. Assoc. 7, $445-451$. 
